\title{
The impact of outsourcing in QMP toward retailing performance
}

\author{
Chong Chiz Chzee
}

\begin{abstract}
Even though many body of research theoretically asserts a positive relationship between quality management practice (QMP) and business performance, a valid measure of QMP has not been proposed and systematic analysis of its effect on business performance has thus future not promising. This paper attend to some conceptual and measurement issues related to the study of QMP and its impact on business performance in service context. It first reviews the concept of QMP and its important dimensions. Next, a measurement scale with acceptable reliability and validity is developed to capture the dimensions of QMP. Sequentially, analysis of data shows that QMP is positively and significantly associated with sales growth, customer retention, market share, ROI, and overall performance. The implications of these findings are discussed and the limitations of the study as well as future research directions are addressed.

Purpose - the purpose of this paper is to discuss the interlinking of quality management practice, outsourcing and performance in the retailing service organizational and, based on that discussion, propose and examine the implications of service organizational framework that incorporates not only the customer's satisfaction but also the employee's perspective and a typology for classifying service effectiveness on the basis of their potential impact on organizational from the Quality Management's practice and the employee's perspectives.

Design/methodology/approach - The service organizational framework and outsourcing typology are developed by synthesizing - and extend - concepts and insights from the relevant literature pertaining to QMP, outsourcing and performance

Findings - contribute the absent relation between management commitment and organizational performance in literature studies on service marketing.

Originality/value - The integration of conventional performance concepts with key insights from the rich literature on outsourcing is relational. The resulting expanded service performance framework and outsourcing typology have important managerial implications and also offer several potentially possibility for further research.

Keywords Performance, Quality management practice, services quality, outsourcing
\end{abstract}

\section{Introduction}

Traditional retails businesses based on customer satisfaction (Anderson et al., 1994). Customer satisfaction is the degree to which the customer believes that the expectations are met (Hofstede's, 2001). This assumption is no longer valid however invalidate the usefulness of the SERVQUAL items to develop alternate measures of service quality (Cronin, Taylor, 1992; Brown, Churchill, \& Peter,1993).Many researchers (Zahorik, Rust, 1992; Greising, 1994; Cornin \& Taylor, 1992) had shown that the SERVQUAL items must be customized to the service setting the question. The relationship between service quality and performance outcomes has been a focal point of interest in the service quality management literature (Carman, 1990; Finn \& Lamb, 1991; Brown, Churchill, \& Peter, 1993). Interestingly research has shown that the link between service quality and business performance is neither straightforward nor simple (Zahorik, Rust, 1992; Greising, 1994; Holmlund, 2007). Indeed Cornin and Taylor, (1992) found that their performance-based measure of service quality was an antecedent of customer satisfaction and that customer satisfaction exerted a stronger influence on purchase intention than did service quality.

Moreover according to Gryna, Chua and Deofeo, (2007) which says quality management is a neverending procession of new techniques for helping develop quality strategy to enhance profitability. Therefore it shows how important to maintain and sustain effectiveness because the Malaysian service sectors strength include a vast variety of sectors from pure service like many professional services, to services that contain significant elements such as factory, hypermarket, banks, hotels, restaurant and many others. Indeed include value added (e.g. Ulaga, 2001) and risk (Cavinato, 2004; Norrman \& Jansson, 2004) such as in-transit assembling, security tagging, bar coding, product reworking, order picking, price tagging, call centre support services, sorting, delivery confirmation and many others. Beyond than from literatures studies, it had identified developing countries that the services account enclosed for more than half of the economy gross domestic product. The gross domestic product (GDP) of economy countries usually covers around $70 \%$ in many highly developed economies. Particularly the Malaysian firm contribution of services industry to the economy as stated in the below table 1 . The assumption can be evaluated using a "goodness of fit", for gathers information 
by observation of customers rather than inquiry of customers. These opportunities must then be translated into specific product quality goals, which, in turn, help to create a unique competitive advantage.

Tables 1

Gross Domestic Product (GDP) of Economy

\begin{tabular}{|c|c|c|c|}
\hline Sectors & $\begin{array}{l}\text { Malaysia Economic } \\
\text { Change (\%) } \\
200720082009 \\
\end{array}$ & $\begin{array}{l}\text { Reports 2008 } \\
\text { Part of GDP }(\%) \\
200720082009 \\
\end{array}$ & $\begin{array}{l}\text { GDP by Sector } \\
\text { Contribution to GDP growth \% } \\
200720082009\end{array}$ \\
\hline Agriculture & $\begin{array}{lll}-6.25 & -3.9 & 2.0\end{array}$ & $\begin{array}{lll}5.4 & 7.4 & 4.6\end{array}$ & $4.6 \% \quad 4.5 \% \quad 5.2 \%$ \\
\hline Forestry and fisheries & $\begin{array}{lll}7.4 & 6.6 & 4.8\end{array}$ & $\begin{array}{lll}5.6 & 6.6 & -1.2\end{array}$ & $6.3 \% \quad 0.4 \% \quad 0.4 \%$ \\
\hline Mining & $\begin{array}{lll}5.6 & 6.5 & 4.3 \\
\end{array}$ & $\begin{array}{lll}6.5 & 4.8 & 5.9\end{array}$ & $\begin{array}{lll}5.9 \% & 7.0 \% & 7.0 \%\end{array}$ \\
\hline Manufacturing & $\begin{array}{lll}4.8 & 0.1 & 2.1\end{array}$ & $\begin{array}{ccc}7.2 & 0.1 & 7.1\end{array}$ & $\begin{array}{lll}7.1 \% & 5.4 \% & 5.4 \% \\
\end{array}$ \\
\hline Construction & $\begin{array}{lll}4.5 & 5.5 & 5.2 \\
\end{array}$ & $\begin{array}{lll}6.3 & 4.6 & 5.3 \\
\end{array}$ & $\begin{array}{lll}5.3 \% & -2.1 \% & 1.2 \% \\
\end{array}$ \\
\hline Services & $\begin{array}{lll}3.9 & 4.7 & 2.7 \\
\end{array}$ & \begin{tabular}{lll|}
6.5 & 7.2 & 4.8 \\
\end{tabular} & $\begin{array}{lll}4.1 \% & 4.5 \% & 5.2 \% \\
\end{array}$ \\
\hline GDP & $\begin{array}{lll}2.1 & 3.5 & 4.5\end{array}$ & $\begin{array}{lll}100 & 100 & 100\end{array}$ & $\begin{array}{lll}2.1 \% & 3.5 \% & 4.5 \%\end{array}$ \\
\hline
\end{tabular}

Source:-Based on Department of Statistics Malaysia, Malaysian economy grown 4.5 per cent in the fourth quarter of 2009

Thus the unique competitive opportunities information on customer needs be translate into specific product attributes and features. These development encourage develops the demand for holistic marketing services knowledge. It recognizes every aspect in marketing such as relation marketing, integrated marketing, internal marketing and social responsibility marketing excellence. These radical changes on interlinking society forces created new behaviours, new opportunities and new challenges. On the other hand the society marketing concept calls upon markets to build social and ethical consideration into their marketing practices. Therefore retailing providers must balance and juggle the often conflicting criteria of company profits, consumer satisfaction and public interest. Firstly the configuration demands tremendous growth in the service sector employment and the services sector contribution for many countries GDP. Secondly this is also due to the deregulation of many service industries (Changa, Chiub, \& Chena, 2010; Gronroos, 2006) and thirdly due to changes with respect to how service firms should manage their services. Even then the time consumption warranty to customer ought to be unlimited or infinite (Ng, 2007). Commonly the companies or firms might reduce or defect waste or zero defect (Gryna et al., 2007; Arumugum, 2008; Wilwaukee, 1999) for their product. In circumstances that adopt outsourcing approach, retails enables firms to proactively seek information on customer preferences and needs, and then become more responsive. Outsourcing firms provide efficiency, inventory improvements and capture the wealth of market scale.

However it seem lack of research, it is important to understand the value stream management which consists of all activities required to bring a product from conception to commercialization. It includes design detail, order taking, scheduling, production and delivery. By co-adjustment value-added activities transform or shape material or information for service quality (Samson \& Terziovski, 1999). In addition this antecedent offers unique challenges to quality management practice for service quality (Changa, Chiub, \& Chena, 2010).

Quality management practice (QMP) is the concept of quality has formerly been discussed exclusively in relation to products, i.e., the goods and services which an organization produces and supplies. Nowadays, quality is increasingly discussed in a broader context. The concept most commonly referred to is total quality, which includes the quality of all internal processes and functions as well as the involvement of everyone in the organization. In this context, reference is often made to the term "total quality management." An increasing number of conference papers referring to total quality management in the title are being presented. Many of the papers, however, do not actually deal with total quality management but include current relational qualityactivities assessment (e.g., the Baldrige Award or ISO 9000) (Gryna, et al., 2007) especially in marketing holistic. They propagate certain narrow concepts or tools. Presentations on the experiences of companies in developing countries really practicing total quality management are, in fact, rare. Below Table 2 shows various finding definitions of QMP in many literatures.

Table 2: Definition finding of Quality Management Practices

\begin{tabular}{|l|l|}
\hline Authors & Definition \\
\hline Changa, Chiu and Chen, (2010) & $\begin{array}{l}\text { Government employees' loyalty is likely to be influenced by the level of their job } \\
\text { satisfaction, and thus maintaining a loyal workforce is a prerequisite for a successful TQM } \\
\text { implementation }\end{array}$ \\
\hline $\begin{array}{l}\text { Masahiro Miyagawa and Kosaku } \\
\text { Yoshida, (2005) }\end{array}$ & $\begin{array}{l}\text { TQM is an effective method to improve business performance regardless of where the } \\
\text { company might be operating, as long as the TQM practices are implemented appropriately. }\end{array}$ \\
\hline Liyin Jin, (2005) & $\begin{array}{l}\text { Five service dimensions reveal that reliability is most closely associated with service } \\
\text { quality system, since it is concerned with the dependability and accuracy of the service. }\end{array}$ \\
\hline M. Holmlund, (2010) & $\begin{array}{l}\text { Set out to structure and synthesise current ways of working with quality, primarily in the } \\
\text { business-to-business sector. Four different scopes on quality are distinguished and } \\
\text { compared in terms of typical features and underlying assumptions: production, service, } \\
\text { relationship, and network. Corresponding to the current business and academic trend, }\end{array}$ \\
\hline
\end{tabular}




\begin{tabular}{|l|l|}
\hline $\begin{array}{l}\text { Peter K.C. Lee, W.M. To and } \\
\text { Billy T.W. Yu, (2009) }\end{array}$ & $\begin{array}{l}\text { Exists different patterns of ISO 9000 implementation; and if so, whether organizations } \\
\text { with different ISO 9000 implementation patterns produce different performance outcomes } \\
\text { and exhibit different contextual factors. }\end{array}$ \\
\hline Woan-Yuh Jang, et al., (2008) & $\begin{array}{l}\text { The relationships among the internal and external motivations and the depth of ISO 9000 } \\
\text { implementation could help clarify the reasons for the failure of some externally-driven } \\
\text { companies }\end{array}$ \\
\hline YUEN Sheung Man, (2006) & $\begin{array}{l}\text { 3PL (outsourcing) is a relationship between a shipper or customer and a third party, and, } \\
\text { compared to ordinary service, offers more comprehensive, customized, and multipurpose } \\
\text { services. }\end{array}$ \\
\hline
\end{tabular}

Quality management practice (QMP) introduces a new philosophy that integrates a variety of business process. Quality management practice defined as quality in a network setting that the focus is on the whole valuecreating chain of activities, ranging from the supplier's supplier to the customer's customer, or the end customer to enhance competitive holistic, regularly correlated with the ISO 9000 series (Lee, et al., 2009). Effective retails and quality management practice is the important factor to organizational success. The service quality and quality management practice strategies can propose Malaysia be a leading or hubs commercial trade centre in Asian region even for worldwide especially in Islam region. Thus high quality and effective quality management is important to facilities service for developing relational activities with network and increase competence (Krajewski, \& Ritzman, 2002).

Quality management practice (QMP) involves the use of outsourcing services means of desire more benefits and performing many of the associated functions at superior levels according to Changa, Chiub, \& Chena, (2010). Outsourcing, which is called "managerial competencies" has shown significant efficient and influencing over the past (Leonard, 2003; Muhammad, 2011). Accordingly outsourcing is a relationship between a retailer or customer and a level quality, and, compared to ordinary service, provide more comprehensive, customized, and multipurpose services. In addition the literate (Gummesson, 1998; Silvestro, 1998; 2001; Parasuraman, 2002; Hough, 2004; Landrum, Prybutok, Zhang, \& Peak, 2009) state that outsourcing is also characterized by a long-term, more mutually beneficial relationship between service providers and customers. Companies that update their retails activities to outsourcing providers promote interactive relationships. It is important to build up organizational connections that adopt a relational, rather than transactional, corporate approach (Landrum et al., 2009).

There is familiar opinion with researchers about the definition of quality management (Change, et al., 2010, Liyin Jin, 2005; Holmlund, 2007). Holmlund, (2007) propose that a quality management practice is crossfunctional teams, quality control circles, re-engineering, quality action teams, creative idea suggestion systems, process improvement teams, quality in daily work, and many others. Even more literatures of quality system and effectiveness service organization studies full up with potential benefits of ISO 9000 (Hashim et al.,2008; Terziovks et al.,2003; Kamal et al.,2004; Eitan et al.,2004; Han et al.,2007 and others). For instance, the outsourcing is able to configure with the management systems used by organizations to design, produce, deliver and support their products/services. Thus shows the standards apply to all broad product categories such as hardware, software, processed materials and services. Well implementing quality management guidance or quality assurance requirements or supporting technology means is adding up variety of value added services. Below table 3 is the moderating of added-values for QMP

Table 3: Definition finding moderating of added-values Quality Management Practices

\begin{tabular}{|c|c|c|}
\hline no. & References & Definition \\
\hline & $\begin{array}{l}\text { Mehra, S. and Rhee, M. (2009); On the } \\
\text { application of quality management } \\
\text { concepts in education: An example of } \\
\text { a Korean classroom. International } \\
\text { Journal of Quality \& Reliability } \\
\text { Management, Vol. } 26 \text { No. 4, 2009, pp. } \\
312-324 \text {, Emerald Group Publishing } \\
\text { Limited. }\end{array}$ & $\begin{array}{l}\text { Numerous writers have indicated that the changing business world needs } \\
\text { more congenial and harmonious relationships in the workplace for } \\
\text { businesses to compete successfully (Weller and Hartley, 1994; Mintzberg, } \\
\text { 2005). For instance, trustworthy dealings between buyers and suppliers on a } \\
\text { long term basis are necessary in the current business environment (Green } \\
\text { and Inman, 2005; Sirias and Mehra, 2005; Bateson and McGough, 2006). } \\
\text { To impart sound people skills, Fellers (1996) suggests the use of } \\
\text { cooperative model of education in colleges for developing increased people } \\
\text { skills. Our objective in this paper is to examine how certain total quality } \\
\text { management (TQM) elements like teamwork and empowerment can } \\
\text { facilitate cooperative learning, and hence, increased people skills. First, let } \\
\text { us briefly visit a few basics of cooperative learning. }\end{array}$ \\
\hline & $\begin{array}{l}\text { Toremen, F., Karakus, M., Yasan, T., } \\
\text { (2009); Total quality management } \\
\text { practices in Turkish primary schools. } \\
\text { Quality Assurance in Education, Vol. } 17 \\
\text { No. 1, 2009, pp. 30-44, Emerald Group } \\
\text { Publishing Limited. }\end{array}$ & $\begin{array}{l}\text { As a human focused approach, TQM can make important contributions to } \\
\text { the increase of quality of education and the improvement of educational } \\
\text { organizations. As, both the inputs and outputs of the educational } \\
\text { organizations are human beings, and human beings are the main actors } \\
\text { at all levels and in all processes of these organizations, without the } \\
\text { satisfaction of human beings (both as customers and providers), it is very }\end{array}$ \\
\hline
\end{tabular}




\begin{tabular}{|c|c|}
\hline & hard to ensure the effectiveness of educational organizations. \\
\hline $\begin{array}{l}\text { Joiner, T. A. (2007); Total quality } \\
\text { management and performance: The } \\
\text { role of organization support and co- } \\
\text { worker support. International Journal } \\
\text { of Quality \& Reliability Management, } \\
\text { Vol. } 24 \text { No. 6, pp. 617-627. Emerald } \\
\text { Group Publishing Limited. }\end{array}$ & $\begin{array}{l}\text { Within the context of successful TQM implementation, there is increasing } \\
\text { recognition of the importance of human factors in quality management } \\
\text { (Brah et al., 2002; Chen, 1997; Fok et al., 2000; Golhar et al., 1997; Montes } \\
\text { et al., 2003). Many of the basic elements of TQM involve people, such as } \\
\text { teamwork, participative management, creativity, effective communication, } \\
\text { customer feedback, employee involvement and empowerment, employee } \\
\text { and management trust and support (Guimaraes, 1994). } \\
\text { This study also found that co-worker support and organization support } \\
\text { moderated the relationship between TQM implementation and organization } \\
\text { performance. } \\
\text { Evidence from this study signals the importance of developing an } \\
\text { environment or "culture" of support to further enhance the performance } \\
\text { outcomes of TQM implementation. If employees do not feel there is } \\
\text { acknowledgement and support from the organization and from work } \\
\text { colleagues, then the implementation of TQM programs may be sub-optimal. }\end{array}$ \\
\hline $\begin{array}{l}\text { Sakthivel, P. B. and Raju, R. (2006); An } \\
\text { instrument for measuring engineering } \\
\text { education quality from students' } \\
\text { perspective. The Quality Management } \\
\text { Journal, 13(3), 23-34. }\end{array}$ & $\begin{array}{l}\text { Therefore, similar studies measuring the level of quality of education as } \\
\text { perceived by the students could be duplicated in develop economies. Such } \\
\text { transnational study could be used to investigate the cultural influences in } \\
\text { implementing an effective TQM program so that a comprehensive picture } \\
\text { of the engineering education across different cultures and multiple service } \\
\text { settings in the world scenario would emerge. }\end{array}$ \\
\hline $\begin{array}{l}\text { Improving service performance } \\
\text { Brendan J. Gray, Sheelagh Matear and } \\
\text { Philip K. Mateson. (2002) }\end{array}$ & $\begin{array}{l}\text { To improve marketing firm should improve their level of market } \\
\text { orientation, develop a corporate culture which emphasizes the marketing } \\
\text { concept and innovation, adopt more proficient new product development } \\
\text { processes and explore possibilities of electronic commerce }\end{array}$ \\
\hline
\end{tabular}

Although there are many reviews and studies of quality management of value added services but, no study has previously set the outlook. Kuei et al., (2001); Hough, (2004); Khalid et al., (2006) and Holmlund, (2007) propose that a chain of interconnected network that forward supplier's supplier to the customer's customer, or the end-customer. In this approach, companies get to make the network or sets plan more competitive as one. This approach is evaluation of current relational activities and assessments that focus on evaluation of the current quality systems, with little emphasis on customer satisfaction results. In either case, the assessment can be performed by the organization itself (self-assessment) or by an outsourcing organization. Thus the studied by Mei, Mile \& Danny (2008) had explored the relationship between ISO 9000 certification and organization performance by developing an ISO 9000 relationship model. The output results, they discovered and identify significant relationship between certification practices with operational performance.

Quality management practices represent new value that integrates integration with marketing discipline a variety of business processes. The quality management practice define as activities that are in a key point, closest to the customers and able to pressure how the customers observe interactions with the company that supply products, add-value, information and services for customers and stakeholders. It involves the results of planning and organising, and implementing all the work indeed. Organizational commitment is strongly related to business and operational performance. It means company which is more in tune with their customers more aware of how the company is perceived in the marketplace and much more likely to deliver consistent, coordinated and positive customer experience, than product-Centralized companies (Judith 2003). Quality management practice comprises a set of values that each quality activities direct and indirect affects the performance all of the others network and all quality scopes performance (Holmlund, 2007).

Universally, employees always give the best effort to offer higher quality to customer satisfactions. So it is important to sustain outsourcing operation to enhance service organization. Many researchers such as Chow et al, (2002) clearly defined that the comparisons between non certificate and certificate listed companies can cause reduction in business cost, whereby certified listed companied can perform better than none certified. Particularly the term of ISO e.g. ISO 9000 is an international standard of goods and service. The term standard for quality tends to be a guide or direction for those companies needs, which must completely be compatible with the total quality philosophy. Accordingly to most researches that all resources and activities must be channelled affection to strive for excellence and also continuously forever improve service organization (Fotopoulos \& Psomas 2010; Brache et al, 1988; Mitchell, 1999; Arumugam et al, 2008). Perhaps it also increases sustainable ability to compete in the market (Rushami et al, 2005; Han et al., 2007) to be more convincing to the customers with a certain approach such as guarantee as promised.

Furthermore many researched recommended approach to initiating quality management practice is to analyze historic commodity spend profile and isolate factors of the commodities service organization effectiveness (Aliah Hanim, 1999; Loi, 2010; Rummler, \& Brache, 1995; Feng et al, 2008; Ramayah, Samat \& Lo 2011). The "criticality of QMP" is commodities, sourcing teams should be established, strategic supplier 
should be identified and selected, and an ongoing team effort involving end users, purchasing, and the supplier should manage value within the quality chain. Once the business target is set it should set challenge targets to stretch them to meet new higher levels of capital market performance such as creative synergy for service organization. In meaning a critical issues for understanding of the customer's values and expectation is essential (Changa, et al., 2010).

Thus only with efficient retailing and quality management practice can capable to promote benefits which aim to clarify the direct and indirect effects between employees in the presence of satisfaction and loyalty. Perhaps it is not just improve retails services quality, more important that it adds value migration, responsiveness, and process integration improvement to generate harvest economy growth. Indeed resource allocation can more be efficient and customer satisfaction to achieve in business.

As business widen its scope and horizons, retails and service management become increasingly more challenging and comprehensive. The shift towards the relationship level introduces totally new management quality whereby mean that they work closer together with either customers or suppliers and works together with both types of complement in a relationship-oriented approach. Perhaps the importance of retails industry in Malaysia is reflected in tremendous growth in factories, consultants, cargo, hyper-shopping, airport, cybervalley and others over the years, and especially import / export. This can explain that retails and service management adaptive, effectiveness and efficiency in business processes, indeed encourage development of various worldwide businesses (Gryna, et al., 2007).

Effective retails and Quality Management practice (QMP) business provide profits, which include assessment maximization, integration practice, and improvement (Muhammad, 2011). They can achieve satisfaction/ dissatisfaction and efficient network chain. In the network background, the focus is on the full value-creating chain of activities, ranging from the supplier's supplier to the customer's customer, or the endcustomer. Hence the integrative benefited grow besides setting of greater outsourcing, globalization, the arrival of new services and longitudinal approach (Holmuld, 2007). In future more investigation on further development of retails and quality management practice activities for synergy sustain. Thus many Malaysia retails have indicated a strong interest in the revamping and integration of their relational activities with worldwide operations.

Regionally, the Asian markets set up stable and sustain growth steady especially our country Malaysia. Reason that Malaysia either economy, geography, people, material, politic, disaster and others are free from great lost/ damage. As knowledge that the government Malaysia vision is become industrialization country by 2020. This transforms Malaysia as a worldwide market whereby the strong government and well develop country as trust. Malaysia is heavily dependent on agribusiness and exports. Thus the government transformation programme, retails industry is the backbone of the Malaysia economy, due to Malaysia's geography strategic location, and its free zone.

Malaysia government is intensively develops rural area through the Government Transformation Programme (GTP) which was introduced by the Prime Minister on $11^{\text {th }}$ July 2009 with the 7 National Key Result Areas (7NKRA). The 7NKRA programme implement a series of policies and recommendations from professionals, politicians, experts and many other organization to maintain and strengthen Malaysia's services and retails hub in region possibly Asian region.

In the prime minister speech addressed that the goal of establishing Malaysia as multi-model trade management and business centre. The government efforts to help the people lessen their burden due to rising costs are continuous. The sustainability and improve performance quality management practices development of an empirical taxonomy provides different contextual factors. The quality management standards have great impact on global/local trade; and quality systems had implemented by many large organization world widely. Moreover, the International Standards have adopted as national standard by over 100 countries. Regards to information of ISO (2009b); numbers with adopted certifications 1,064,785 worldwide; while our country Malaysia consists of no. 6,267 participants. They are implemented in a huge range of sectors such as production, economic and government regulatory. The objective to enhance the capacity of government and to create an ideal environment for investment and economic growth, the government has undergone a series of reengineering processes, including the civil service (Hashim et al, 2003; Terziovks et al, 2003; Kamal et al, 2004; Eitan et al, 2004; Han et al, 2007).

Nevertheless with regard to human resource development, it was found that an employee responsibilities and concerns together with strong efforts to resolve the problem will help to diffuse the problem in the customer minds. With regard to employee participation and labour union, it was found that compensation and technology must be exercised within the framework of mature methods and practices in order for productivity, reliability, speed, and coherence to be forthcoming. In subsequent for general matter, it was found that paying the customer lip service was not enough - a firm needs to take responsibility, strategy and follow through the problem and solve it (Tax et al, 1998). Instead that with the evolution of technology made the need for Malaysian standardizing certain concepts and practices. Importantly Gryna et al., (2007) had note that the quality functions 
comprise both technical quality activities and strategic quality management activities. They also state that retailing must be made to staff a quality department with skills in those two areas. The first element of design control is an organized plan for establishing design and development activities. The plan defines the activities to be conducted in support of the design effort and the parties responsible for each. The computer revolution has also been a primary force in the expansion of quality activity into service businesses and functions.

Indeed many researched shown that the problem solving effectively has a strong on customer satisfaction, loyalty and bottom line performance. By right in order to maintain good performance or outstanding in all Malaysia retailing business expectation, the company should update to improve their customers experiences vastly. Therefore this study will fill in this gap, and other gaps identified in the problem statement. Only with excellent understanding will satisfied the QMP efforts done by the firms will enhance their competitive strength, quality management practice providers must well prepared to adapt other demands and challenges especially in retailing industries.

\section{Theoretical framework}

The theoretical framework as refers to Sakaran, (2000) is that the relationship among the variables to investigate. The research framework is formulated through literate studies on the service quality, quality management practice and outsourcing theories and philosophies.

Based on the literature previous chapters and sections, eight independent variables that involve the Quality Management practice strategies were identified selected and operationalised. The variables strategies quality is 1) leadership, 2) information and analysis, 3) strategic planning, 4) human resource and labour union, 5) assurance of products and services, 6) supplier, 7) customer focus and satisfaction, and 8) Continual improvement; 9) the dependent variable is service performance; and 10) the moderator is outsourcing.

Figure 1: shows the Conceptual relationship of the ten variables of the study. The relationship content of eight direct relationships of the independent variables; five dependent variables and one moderator

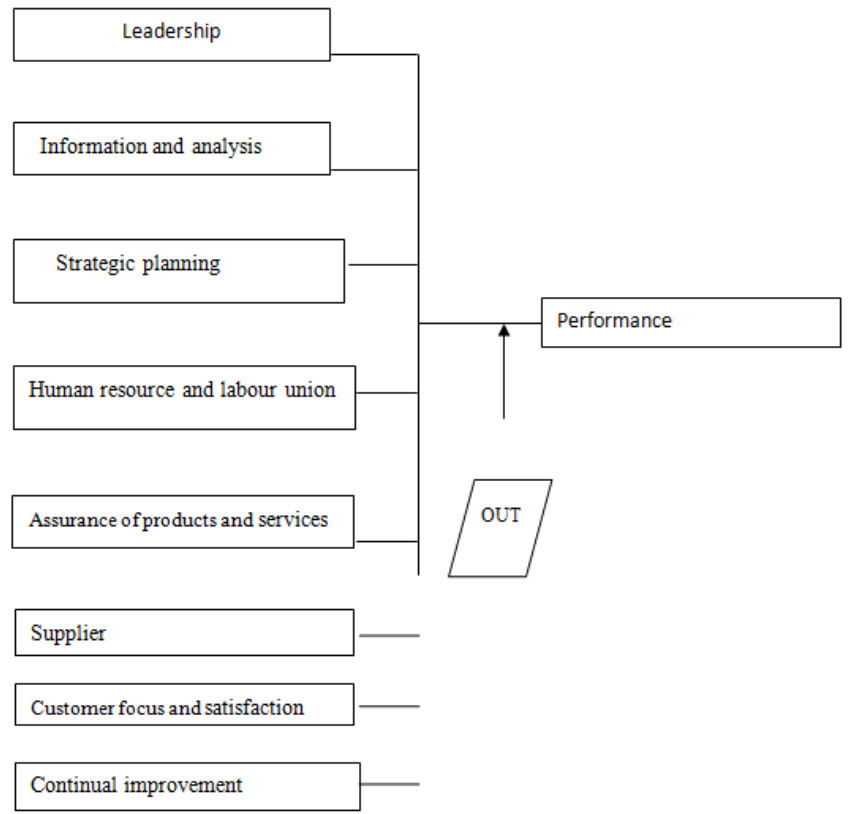

Figure 1 the theoretical framework of study

The figure 1show that the discussion in earlier chapter which the quality management practice (QMP) strategies influenced service performance to identify the context - structure - output approach to the organizational performance of retails companies. The following details choice of a systemic set-up hierarchy of the performance measurement retails outsourcing. Therefore this study conceptualized eight direct relationships as follow;

1) The relationship between leadership and service performance.

2) The relationship between information and analysis and service performance.

3) The relationship between strategic planning and service performance.

4) The relationship between human resource and labour union and service performance.

5) The relationship between assurance of products and services and service performance.

6) The relationship between continual improvement and service performance.

7) The relationship between customer focus and satisfaction and service performance.

8) The relationship between supplier quality and service performance. 
The following section discuss on the service quality.

The construct of quality in the services literature focuses on perceived quality, which is defined as a consumer's judgment about an entity's overall excellence or superiority (Zeithaml, 1987). This approach differs from that of objective quality, which involves an objective assessment of activity or event. Perceived quality is a form of "attitude", resulting from a comparison of expectations with perceptions of performance. However, despite the emphasis in the literature on this approach, perceived service quality has remained an elusive concept (Brady and Cronin, 2001; Parasuraman et al., 1985).

Many have suggested that quality results from a comparison of perceived performance with expected performance - based on the so-called "disconfirmation paradigm". Indeed, this notion was the basis for the SERVQUAL model, which views service quality as the gap between the expected level of service and customer perceptions of the level received (Parasuraman et al., 1988). SERVQUAL identified five determinants of service quality:(1) Reliability; (2) Assurance; (3) Tangibles; (4) Empathy; and(5) Responsiveness. Conceptually, these constructs address, respectively, performance standards, expertise and physical elements of the facility, employees' willingness to assist in a timely manner with their knowledge, and sensitivity. Although SERVQUAL has been extensively used in assessing services quality, it has also been subject to criticism in various respects - including its use of the "difference score", its dimensionality, its applicability, and so on (Asubonteng et al., 1996; Buttle, 1996; Cronin and Taylor, 1992; Carman, 1990; Babakus and Boller, 1992).

In addition, SERVQUAL has also been criticised for focusing solely on the service-delivery process (Gro" nroos, 1990; Mangold and Babakus, 1991; Richard and Allaway, 1993). In this respect, it is of interest that one of the underlying themes of SERVQUAL was that: "Quality evaluations are not made solely on the outcome of service; they also involve evaluations of the service delivery process" (Parasuraman et al., 1985). However, despite this, it is difficult to find an explanation for their failure to address outcome (technical) quality in the SERVQUAL instrument. It would seem that technical quality has been neglected in SERVQUAL's measurement of service quality.

Despite these concerns, much of the previous service-quality research has concentrated on the SERVQUAL instrument, and has thus focused on the functional-quality dimension. Few, if any, efforts have been made to test a two-component model of service quality that includes both technical quality and functional quality. Subsequently that guanxi is basically ethical and it can be used as a positioning strategy in China. However, there is some evidence to suggest that guanxi and favor are sensitive and situation-specific, but further research is needed to confirm these claims. The purpose of the present study is therefore to extend understanding of outsourcing by empirically examining a conceptualization of service quality that includes both technical quality and functional quality.

The following sections discuss on the relationship between relation management, outsourcing and service performance indeed; how the hypotheses were developed would be explained in next part e.g. section 2.1 and 2.2 .

\subsection{Relationship Management}

In service management requisites, quality management practices (QMP) strategies is focused on relational management and on the flow of communication and materials to deliver enhanced customer services. As research in Sabrina \& Sandra, (2008) and Gi-Du, \& Jeffrey (2004) claims that area develops may be able to better understand when felt trust leads to enhanced performance and when it does not. For example, availability of resources may moderate the relationship between collective felt trust and affects customer service through affective variables, such as positive mood. Clearly, additional empirical research is needed to fully understand how being trusted by management influences customer service

Regarding to Juran et al., (1998) that operations in the service sector (and the manufacturing sector) are involves in addressing sporadic problems and also chronic problems. The actions required include troubleshooting, quality improvement, and quality planning. Maintaining the focus on improvement clearly requires a positive quality culture in an organization according to quality policies. As planning for service quality refer to Gryna, et al., (2007) that an operations function must be provided with the support to maintain the focus on improvement which says operations as a key internal customer and provide training and technical quality expertise to support operations indeed.

In measuring performance, terms like customer satisfaction and quality are too foggy refer to Gryna et al., (2007). Based upon the literatures studies (Cronin \& Taylor 1992, Babakus \& Boller 1992; Brady et al., 2002; Landrum \& Prybutok 2004; Landrum, et al., 2008) their findings service quality utilizes the five of the seven SERVQUAL. Landrum et al., (2009) states many researchers claimed that the performance only subset instrument service quality. In terms of service management, linkage network is focused on service quality and on the flow of information and materials to deliver enhanced service organization. Berry (1995) describes relationship management as the attraction and maintenance of customer relationships to secure loyalty and retain existing customers. In fact Lambert and Stock, (1993) identified that service organization traditionally aims to 
attract and keep customers, an expanded view that encompasses the enhancement of customer relationships is warranted in quality management. Because quality management relationships are built on long-term partnerships, a focus on loyalty assurance is important. The objective of customer relationship enhancement and loyalty assurance of guaranteeing repeated purchases is not likely to be sufficient in strategy operation management. The focus should instead be on the enhancement of interaction in the relationship to improve strategy operation performance generally. In sequent as refer to Lambert \& Stock, (1993) this raises the question of how customer service interfacing influences the satisfaction and loyalty of intermediary customers and, as a result, the degree of cooperation and information exchange between firms indeed.

Relationships key strategies in marketing include the tailoring of the relationship to individual customers, core service augmentation with extra benefits, service pricing to encourage customer loyalty, and employee marketing to encourage the improvement of customer service performance (Berry, 1995). Internal activities that aim to establish, develop, and maintain "successful relational exchanges are mutually beneficial. At advanced levels of relationship marketing, structural solutions to the problems of important customers are critical elements of the services that are provided.

Importantly according to Ross, (1998) which says quality management is a philosophy that coordinate internal and external capabilities to create market value and allow members to focus on finding new ways to create unique and innovative key that provide value to customers on an individual basis. Indeed trust, responsibility, and integrity are three major elements in relationship management between providers and their customers. This focuses on the elements that are important in efficiency, flexibility and dependability as management activities or organizational processes. To achieve customer service improvement in a strategy operation as a means of value creation, service quality, and differential advantage achievement, firms must focus on the development of appropriate strategies that are based on their understanding of consumer needs, and on the development of the capabilities of the operation management to meet those needs in a cost-effective way.

The differences in service requirements across customer segments must be understood, and organizational processes must be designed to allow firms to respond to the different requirements of strategic customer segments. To accomplish these objectives, customer service interfacing must be managed in a way that enhances the quality of the relationship and encourages the open exchange of information between firms. But important information about customers must be distributed and utilized to focus operation management activities on the most valuable quality practice. In fact the operation refer to Yuen, (2006) has a critical element of quality practice management is an understanding of the performance outcomes of the quality practice process that customers perceived to be important. This study identifies the service activities of quality management providers and their customers.

\subsection{Determinants and Advantages of outsourcing}

Based on the literatures definitions of outsourcing and measures according to Gryna, et al.,(2007); Yuan, (2006); Neely et al.,(1995); (1996), the outsourcing measurement can be defined as the employment of a set of metrics to quantify efficiency, adaptive and effectiveness of actions indeed. The quality management practice measurement system performs a rudimentary calculation and documentation of events. It integrates critical information on a company inputs, processes and output. The design is usually optimized around a set of delivery methods and media, the implementation planner still has a wide choice of alternatives in arriving at the most effective and also most cost-efficient solution. Thus these measurements influence the future by supporting and shaping subsequent decisions and structures process activities.

Importantly there is a lot of determinants demand of the outsourcing. According to Humphrey et al.,(1992); Bohoris et al.,(1993); Leung et al.,(1999); Magd et al.,(2003); Yeung et al.,(2005); Masahiro \& Yoshida, (2005); Lee et al,(2009); Landrum et al.,(2009) in today`s businesses as the most prominent key driving force increasingly is on quality management practice functions. Moreover Lee et al., (2009) states that lead to more complex network chains organizational management, the effective of quality management practice is more require for larger retails.

Furthermore, refer to Fotopoulos and Psomas's (2010); and Yuen's, (2006) claimed that the uses of quality management (QMP) with promotes 'outsourcing' especially ISO 9000. The Principles promotes development in delivery, inventory, cycle time and others have increasing to manufacturing and services. These complexities have encouraged companies to increase their own knowledge skills and resources with outsourcing their own corporate network.

Thirdly, the path emerging technology and the adaptability of service quality are two other important determinants of outsourcing (Charles \& Kurokawa, 2002). Retails can easily develop outsourcing and implement new technologies. The adaptability of an outsourcing encourages improvements in control, location and technology. Outsourcing service providers refers to Charles \& Kurokawa, (2002) also have the ability to reconfigure the retails system to adjust to the changing technological and markets advances. However Chatterji 
and Manuel, (1993), and Harrington, (1995) states that, the SME companies intend to the indoor scouring uses whereby is in term of lesson learning for technological expertise and assistance. But Robert's research claimed that the higher aggregate level for reliance basic on outsources technology. A need of representative and communications facts about purpose countries forces firms to seek the expertise of outside professional retails. As the service quality achieves flexible commitments through flexible technology strategies with retails provider, it enhances business activities and the success supplier's network.

According to Yuen's, (2006) study found that outsourcing facilitate the overall quality of performance in global relational quality and network chains. Importantly, the outsourcing encourages operational goals, such as the reduced of delivery time and the assurance of accurate loading. Nevertheless, it also promotes competition between retails and motivates according to him that the contribution to renewal and refinement of services (Woan-Yuh, 2008). In these services climate environment, retails outsourcing and their network chain partners frequently grow together and enter into new markets refer to Churchill et al.,(1992). As the service quality achieves flexible strategies with retails providers, it enhances business activities and the success of relationship networks.

In fact Chartterji and Thomas (2001) found that outsourcing is to complement internal $R \& D$ activities emerged as one such challenge. However Foster and Muller's, (1990) had claimed that outsourcing contributes to profits by enabling customers to gain a competitive advantage, adding measurable product value, enhancing customer service, and assisting in the development of new markets and providing dedicated resources. Retails providers improve value creation for customers, consequences increased competitiveness and profitability timely and better customer service (Daugherty and Pittman, 1995).

Therefore outsourcing, according to Patrick,(2011) which says supplier quality involves long-term, mutually beneficial relationships between users and service performance. They recognized that strategic alliances have become a matter of effectiveness service performance, and not just a question of competitive benefit. As refer Walton's study (as cited in Yuen's 2006) claimed that the current satisfaction and future expectation of sharing / quanxi satisfaction as perceived by business executives who are responsible for quanxi implementation. Literate studies (Boulding et al., 1993; Cronin \& Taylor, 1992; Kui et al., 2002; Lee et al., 2009) found that the expectation and perceptions of customers of service processes (information, convenience, personalized attention and flexibility) are important in measurement of customer satisfaction. However as according to Mentzer et al.,(1989) which says traditional quality service measures of speed, accuracy, availability, and consistency. Satisfaction-based loyalty is highlighted an important variable that configuration quality management practice service activity to customer intentions. Thus Lee et al., (2009) suggests the level quality management practice that the service processes configurative with service quality interfacing may enrol customer satisfaction and influence of customer behaviour on retailing.

The study operation and production service quality performance in Malaysia retailing industry can also contain variable insights for further research into the development of a theoretical framework of the performance measurement in Malaysia. A representative list of reasons outsourcing Yuen's studied adapted is presented in Table 4

Table 4: Reasons for Using outsourcing Services

\begin{tabular}{|l|l|}
\hline \multicolumn{1}{|c|}{ Driving outsourcing } & \\
\hline A company's need to assess the present and market forecast of its products & \\
\hline A change in management & \multirow{2}{*}{ Mohammed \& Chang, (as cited in } \\
\hline Company restructuring & \\
\hline The need for quicker inventory modification & \\
\hline The need for flexible production & \\
\hline An increase in environment awareness & \\
\hline An increase in customer demands & \\
\hline Existing facilities and / or systems & \\
\hline Improved productivity measurements & \\
\hline Expansion into new markets & \\
\hline Economizing of core business & \\
\hline Development of supplier network & \\
\hline
\end{tabular}

All the above factors in multi attribute study to an increase in demand for services which in turn quality management practice more intensive competition, process approach operation service innovated by new technologies and increases focus on service quality. More heavily, it translates permanent or pure royalty to their company product and provides long term services to customers. It is important that quality management practice operation service always can ensure and maintain service quality as long their usages. Hence our country's Prime Minister Dato Najib always mentions how important in modern economies are being increasingly driven by services enterprises. He also addresses that it is responsible for creation of a substantial majority of new jobs to the country development and even in the global parts. Therefore it is important to 
understand and transfer the value-added for succession transformation vision. Indeed, the government is committed aggressively to offer capitals and facilities (Holmuld, 2008).

\subsection{Conceptual framework of OUT}

In addition to the context-structure-output framework, there is also has an external factor, relationship management, that affects the organizational performance of retails outsourcing. When outsourcing service providers deliver services to their clients or customers, they often find that the services that are provided in conjunction with the product are considered to be more important by customers than the product itself. It has been revealed that a number of factors that customers consider to be most important to their overall satisfaction are service-related intangibles (Cann, 1995). Parasuraman et al. (1985) determined that many of these factors overlap with service quality. Berry and Parasuraman (1991) reported a 78 similar focus group study, in which the results of desirable service quality such as "being a partner," "being an extension of my company," and "the need to know service technician" were uncovered.

Bowen et al. (1989) claimed that it is important for manufacturing firms to focus on a customeroriented strategy. Two of the factors that Bowen et al. (1989) proposed as critical to a customer service-oriented strategy for such firms included "recognizing the importance of intangibles" and "establishing relational markets." OUT service providers, who once thought that providing a good, reliable product was the key to success, have found that the customer wants more. One participant in the aforementioned focus group interviews indicated that the reliability of the product was not a factor because "you can throw rocks at the box and it will still run" (Cann, 1995). However, the same customer was very concerned about the vendor's attitude toward helping the customer solve problems and the communication of advancements in new technology to the customer. The exponential increase in the demand for OUT has created an extremely competitive marketplace in which most supply chain partners have yet to generate a profit. OUT is a consumer-oriented approach to the management of various partners within a supply chain. A good relationship management, such as one that involves guanxi, trust, and commitment among supply chain partners, enhances TQ organizational performance (Elmuti, 2002).

\subsubsection{Guanxi}

Guanxi refers to relationships or social connections that are based on mutual interests and benefits. It refers to a special type of relationship that bonds exchange partners through a reciprocal exchange of favours and mutual obligations (Alston, 1989; Luo, 1997). Guanxi implies certain preferential treatment for exchange partners in the form of easy access to limited resources, increased accessibility to controlled information, and preferential terms that include credit authorization and protection from external competitors (Luo, 1997; Luo \& Chen, 1997; Wong, 1997; Xin \& Pearce, 1996). Guanxi is believed to enhance a firm's competitive advantage by providing access to the resources of other partners (Luo, 1997). Guanxi embodies relationship-networking attributes. However, the exchanges of favours among the members in a guanxi network are not strictly commercial, but are also social, and involve the exchange of both favours and affection. This feature makes guanxi a form of social investment. In contrast, networking is a Western management term that is associated with commercial relations. Western business people overemphasize the gift-giving component of guanxi and neglect the long-term Chinese goal of building trust (Pearce and Robinson, 2000). Commitment that is established through relational bonding is combined with other external factors such as word of mouth and media reports about the seller to form an overall perception of trust (Conway and Swift, 2000). Thus, the following is hypothesized. Hypothesis 14 (H14): The better the guanxi relationship between an OUT service provider and its supply chain partners, the greater the intent by both parties to maintain a long-term relationship.

\subsubsection{Trust}

Trust is an essential ingredient for a successful relationship (Dwyer et al., 1987; Morgan and Hunt, 1994). Moorman et al. (1993) defines trust as "a willingness to rely on an exchange partner in whom one has confidence." It is proposed that an expectation of trustworthiness is derived a proven ability to perform (expertise), reliability, and intentions. Morgan \& Hunt (1994) defined trust as the perception of "confidence in an exchange partner's reliability and integrity." Both definitions highlight the importance of confidence and reliability in the conception of trust. Employing a similar definition of trust, Gwinner, Gremler, and Bitner (1998) find the psychological benefit of confidence and trust to be more important than special treatment or social benefits in a customer's relationship with a service provider. Morgan and Hunt's (1994) theory of trust and commitment identifies trust as a precursor to vulnerability and sacrifice. It follows that people are unlikely to be committed unless trust is already established. This theory also proposes that trust is influential in the maintenance of the relationship between a user and a service provider. The immediate high transaction costs of the fulfilment of promises may financially be worthwhile in the long-term in exchange for the maintenance of lasting trust with Chinese partners (Morgan \& Hunt, 1994). Trust is paramount for long-term a relationship 
between Tech providers and customers. Commitment is based on trust and in turn generates trust. Nooteboom (1996) concludes that trust is important because transactions that are based on the implicit pre-existing and unspecified cooperative conditions of trust economize on the specification and monitoring of contracts and material incentives for cooperation. Trust is more economical for transactions because it reduces opportunism, which Williamson (1985) identifies as the main source of transaction costs. It also allows greater flexibility, because trust reduces the need for detailed contracts that are difficult (slow and costly) to modify when conditions change. This is particularly important when the goal of cooperation is innovation and learning. Hence, trust may serve as a substitute for governance.

Although early research into inter-organizational exchange recognized the importance of trust (Arrow, 1973), the concept has only been recently thoroughly developed. The concept of trust is still somewhat subtle and diffuse, but it is now accepted that there are different forms of trust that arise from different sources.

Sako (1992) concluded that "trust is a state of mind an expectation held by one trading partner about another, that the other behaves or responds in a predictable and mutually acceptable manner." She maintains that predictability in behaviour can exist for different reasons, and identifies three types of trust: mutual (contractual) trust, competence trust, and good will trust. Mutual trust is based on the adherence by two parties to a specific written or oral agreement. This type of trust is called "contractual trust," and according to Sako is predicated upon both trading partners upholding a universalistic standard of promise fulfilment.

Technical and managerial competence is of issue for the second type of trust, "competence trust," which is based on the expectation that trading partners will perform their role competently. Sako's third type of trust, "goodwill trust," is more diffuse, and is defined as "mutual expectations of open commitment to each other." Goodwill trust is the presumption that trading partners possess a moral commitment to uphold a trading relationship (Sako defines commitment as the willingness to do more than is formally expected). Goodwill trust does not have the explicit expectation of promise fulfilment of contractual trust, or the professional expectations of competence trust. Sako concludes that someone who is worthy of goodwill trust is dependable, discrete, and can be trusted to take initiative without also taking unfair advantage.

In summary, trust is an important relational feature of ongoing inter-organizational exchanges that may serve as a substitute for hierarchical control. It is examined in this research in relation to the management of OUT. The following is thus hypothesized.

Hypothesis 15 (H15): The better the trust between OUT service providers and supply chain partners, the greater the intent by both parties to maintain a long-term relationship.

\subsubsection{Commitment}

As the interactions between two parties exhibits consistency over time, a commitment to one another and to the longevity of the relationship develops (Gundlach et al., 1995). Commitment suggests a binding agreement, in which two parties pledge to continue a relationship.

Commitment is a key feature in a long-term relationship between an OUT provider and its partners. It is an important safeguard for relational continuity, because a committed partner will avoid unforeseen problems that may result from an abrupt termination of the relationship. Problems can also arise in a supply chain relationship, for example, a customer may want the supplier to reduce a price or improve quality. However, the supplier may refuse because it lacks the capability or incentive to fulfil the customer's request. In the following, a concept of commitment that is based on the insights of Helper (1987) is explained Helper applied Hirschman's (1970) general theory of "exit, voice, and loyalty" to analyze problems in supply relationships. She generalized Hirschman's analysis to include the case in which the resolution of problems requires not only efforts by the parties involved, but also by irreversible investment in physical organizational capital. Employing Hirschman's terminology, Helper identified a response to problems that may arise in a supply relationship, in which the voice strategy relies on the "carrot" of increased profits for both parties to improve products. Helper concluded that an extensive communication system is necessary to facilitate the rich flow of information that is needed for the "let's work things out" approach of the voice strategy. This information flow requires and engenders a high degree of commitment to the relationship. Helper's concept of commitment is a refinement of Hirschman's (1970) concept of loyalty. For Hirschman, loyalty determines the distinction between exit and voice. Helper, however, argued that loyalty has two effects in Hirschman's analysis. It is sometimes a force that facilitates the use of voice and is sometimes a response, because loyalty can blind people to the existence of problems. Helper separated these two effects by referring to the first as "commitment" and to the second as the resolution of problems by "ignoring them." Commitment thus refers to all efforts to maintain and continue a relationship. Helper claimed that commitment has three implications. First, it is costly for customers to establish and maintain extensive communication systems with multiple suppliers. Second, there is a need for trust when there is an exchange of proprietary information. Third, customers and suppliers benefit substantially from the knowledge of each other's products and processes that is gained by working together over time. In contrast, an exit-based strategy requires low commitment to maintain the credibility of the threat to leave. Hence, information exchange 
must also be low. Anderson et al. (1994) suggested that cooperation is essential in a dyadic relationship, and that commitment is the consequence. Dwyer et al. (1987) argued that commitment between two parties is indicative of the most advanced stage in a relationship, and that both parties are actively involved in the maintenance of the relationship. Moran and Hunt (1994) considered commitment to be a keystone of relationship management. Once commitment is reached, emphasis in a relationship moves toward cooperation and long-term maintenance of that relationship, so that both parties continue to experience positive and profitable outcomes (Lai et al., 2005). To conclude, commitment is important in overcoming problems that arise in a relationship between outsourcing providers and supply chain partners that features a high level of specific investment, mutual adjustments, and an asymmetric flow of information. The following is thus hypothesized. Hypothesis 16 (H16): The better the commitment between an OUT service provider and its supply chain partners, the greater the intent by both parties to maintain a long-term relationship.

Figure 3.7 shows the research framework of performance effectiveness management.

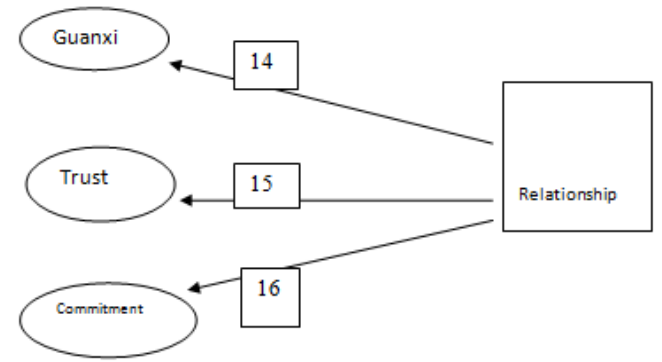

Figure 3.5

Research Framework of Performance Effectiveness Management

Figure 3.5 shows the research model of OUT relationship management.

\section{Methodology}

The breakdown of this methodology explained in following sections: First part is about the research design and the nature of the study. In the following parts, the data collection methods, data collection strategy and the data collection instrument development, operationalisation, measurement of independent dependents and moderating variables were described respectively. Next, the data sampling design, the population, the sampling frames and the sample size are discussed. It is followed by next part in which the administration of the field study is record. Data analysis methods are described in the ending section which is followed by the summary and conclusion to the chapter on methodology.

\subsection{The Development of Data Collection Instrument}

Its objective of development is to identify the significant relationship between QMP and service performance organizational in Malaysia. There are eight independent variables and four dependent variables plus a moderating variable for this study. The validity and reliability are variables subject to test before carried out the fieldwork. Pilot test is carried out in this exercise. Yuen's study (2006) found that the purposes of the pilot study are:

1) Ensure the validity and the reliability, and also task such as stress analysis and part selection.

2) Maintainability quantification follows a familiar approach.

3) A systematic examination of design requirement and the capability of the design in meeting service organization.

4) Forecast any short comings of the questionnaires.

Hence, a set of questionnaires was set that enclosed the following sections:

1) Section Introduction: Question on the introduction that lead respondents into answering the next questions on retail services.

2) Section A: Questions on Leadership.

3) Section B: Question on the quality information \& analysis

4) Section C: Question on the strategic planning

5) Section D: Question on the human resource development

6) Section F: Question on the quality assurance.

7) Section G: Question on the supplier quality

8) Section H: Question on the customer focus \& satisfaction

9) Section I: Question on the service quality

10) Section J: Question on service performance

11) Section K: Respondents' demographic 
12) Section L: Open ended question requesting the respondents for their suggestions on how to improve service quality performance.

The service rally or moment of fact is when the part of interaction between three parties is involved, e.g. consumers, employee participation \& labour union and retailing services which provide the background and create the environment. Most of failure and remedies occur during dyadic interaction, including of quality management practice towards service quality performance this study is examining these eight factors.

The preparation and development of the questionnaires design, wording, quality-related activities scaleitem and statistical sampling plan were prepared in accordance to suggestions by Mizuno(1988), Goldratt,(1997), Dettmer(1995), Zikmund(2003), Warsworth et.al(2001), Hair et al (2000) Gryna et al (2003) to ensure the reliability and validity of the questionnaires. Scales used in the questionnaires is the six point Likert (1961) scale to measure the dependent variable- The numbers 1 through 6 represented a response to each statement of the independent variable in an item : 1) Strongly Disagree; 2) Disagree; 3) Moderately Disagree; 4) Moderately Agree; 5) Agree; and 6) Strongly Agree

So as noted the above was an unbalanced rating scale with non neutral point. The respondents should to read the questions well smart before answering them. There are only two choices of level given, e.g. three choices of level of disagreement on scales 1 to 3 and three choices of level agreement on the scales of 4 to 6 . There is indecisive response like in the ordinary scale where in the middle there used to be a "neutral" or "neither agree nor disagree" choices. The reason for using a six point interval scale is to avoid respondents from ticking the weight in the middle value as commonly found in most surveys (Sekaran, 2003). This measure has also accommodates the needs of researcher for tapping variable. Indeed that the itemized rating scale provide the flexibility and extensively in most research.

For questions in section I (service performance organizational), the following scale was used: 1) Most unlikely; 2) Unlikely; 3) Moderately unlikely; 4) Moderately likely; 5) Likely; and 6) Most like

For questions, the respondents are asked to use the following scale:1) Least probable; 2) Improbable; 3) Moderately improbably; 4) Moderately probably; 5) Probably; and 6) Most probably

The scale was used after deeply observe through more sample study and discuss with experts. However, no sample will ever fully represent the population in all aspects. This is said to be due sampling errors, which is reflected in the influence of chance in drawing the sample members or respondents (Sekaran, 2003) for each purpose, Schiling (1982) recommends specific attributes or variables sampling plans. Selection of a plan depends on the purpose, the quality history and the extent of knowledge of the process. The steps involved in the selection and reduced inspection costs. The row data from a neutral scale response become diagnostically useless to both the researcher and business decision maker. But that the neutral attitude or feeling; these psychology almost always have some level of a positive or negative orientation attached to them. The plan should minimize the total costs of inspection of all products. This requires careful evaluation of the pros and cons of attributes and variable plans, as well as multiple sampling. It should also reflect product priorities, particularly from the fitness-for-use viewpoint. Indeed than the plan should also provide information useful in estimating individual lot quality and long-run quality. Be Note that the plan should simple to explain and administer (Schilling, 1982, p. 564).

\subsection{Measure}

In this sector the guiding framework collecting and gathering relevant data for hypotheses testing to answer the research questions. Generally the methods available for collecting data have been classified into category, quantitative.

\subsubsection{Nature of the Study}

Empirically this to test certain hypotheses values with respect the quality management practice and service performance of the study objective. This is nature correlation study. Therefore, this cross-functional development study involves surveying the perception of respondents in Malaysian retailing using the revised measurement scale. Adopted the Miyagawa and Yoshida (2005) phenomenon sets for favoured better understanding. Importantly refer to Miyagawa and Yoshida (2005) that the cross-sectional unique features learning is the Deming management philosophy which has contributed to the improvement of the Japanese products and services is summarised as follows: first of all, to improve quality by reducing machine troubles and mishandling that enables cost reduction. Secondly, refer to Yuen, (2006) with better quality and competitive prices, resulting in increasing sales, profitability and employment even achieving more market-share. Deming's quality management philosophy was examined in light of businesses practices in Japan as refer to Yoshida, (1995).

Therefore by the study had used a considerable size of data taken at a particular point of time in order to prevent any variable influencing the validity of the instrument. The independent variables were quality Leadership, information and analysis, strategic planning, human resource development, employee participation 
and labour union issues, assurance, supplier, customer focus and satisfaction, and general. Besides that, the dependent variable was service performance organizational and outsourcing is moderating variables. Accordingly $2 \times 2$ sets of completed questionnaires were collected to gain information on the expected retails QMP and service performance of outsourcing (OUT expected), the actual retailing retails QMP and service performance of the QMP provider (OUT actual), the expected retails QMP and service performance of the business homogenous (customer expected), and the actual retails QMP and service performance that were received from the provider (customer actual).

Therefore the aforementioned discussion, the unit of analysis organization, the study is the each group of identical QMP and internal staff as respondents. Random sampling quality management practice employees were divided into two groups. A team of answering expected questionnaire on retails quality management practice and performance by homogenous, and the other team completed the questionnaire on actual retails quality management practice and service performance. Two respondents from each homogenous completed the questionnaire on expected retails QMP and service performance received from the QMP provider.

\subsection{The sampling design}

According to Sekaran (1992) and Zikmund (2003), there are two major types of sampling designs: probability and non-probability sampling. First, the elements have recognises chance or probability of selection in the population for the purpose of wider generalisability. Second condition, determine the number of respondents be selected from each hyper market. 500 respondents roughly needed to represent the population, thereby 30 distributor questionnaires to the respective hyper market through random selection.

\subsection{The population}

Organization as the units of analysis.for this purpose, data will have to be collected from the identical homogenous business and each individual internal staff using the revised measurement scale.

\subsection{The sampling frames}

The Sampling Frames- based on database from Ministry of consumer and cooperate trader affairs (KPDNKK), the population of Hypermarket in peninsular Malaysia

Secondly the stratified random sampling is efficient for probability sampling design (Sekaran, 1992, 2000) especially in procedure.

Processing Technique and Data Analysis

- Statistical Package for the Social Sciences.

SPSS version 19 was used to code the data and to test the hypotheses. Regression is for the analysis to predict the outcome of the relationship. Thus the value of adjusted RxR was observed as it indicated how much those independent variables enhance the relationship towards service performance. From aforementioned statistical analysis, it is inferred whether to accept or reject the null hypothesis and accept the alternative.

- Descriptive Statistic and inference statistic.

-used to describe the sample with regard to demographic profile. Tested with Friedman rank means tests such as normality, linearity, homoscedasticity and multicolinearity conducted. The exercise constructs validity, the principal component analysis.

- Pearson correlation analysis

To answer whether there was difference between the frontline middle/ top managers within the group and among the group of respondents, the data were analyzed using one way analysis of variance.

- Multiple regression analysis

\subsection{Data analysis method}

Questionnaire development and pilot testing

Eight independent variables and four dependent variables are for this study. It also included one moderating variable. The validity and reliability test to the variables before the fieldwork was carried out. Pilot test was performed in this exercise. Than the purpose of the pilot study are to:1) Ensure the validity and the reliability, and also task such as stress analysis and part selection; 2) Maintainability quantification follows a familiar approach; 3) A systematic examination of design requirement and the capability of the design in meeting service organization; and 4) Forecast any short comings of the questionnaires.

Thus, a set of questionnaires was prepared that covered the following sections:1) Section Introduction: Question on the introduction that lead respondents into answering the next questions on retail services; 2) Section A: Questions on Leadership; 3) Section B: Question on the quality information \& analysis; 4) Section C: Question on the strategic planning; 5) Section D: Question on the human resource development; 6) Section E: Question on the employee participation and labour union; 7) Section F: Question on the quality assurance;8) Section G: Question on the supplier quality; 9) Section H: Question on the customer focus \& satisfaction; 10) 
Section I: Question on the outsourcing; and 11) Section J: Open ended question requesting the respondents for their suggestions on how to improve service quality performance.

The quality management practice or moment of truth is when the part of interaction between three parties is involved, e.g. strategic planning process, employee participation \& labour union and Leadership which provide the background and create the environment. Most of failure and remedies occur during dyadic, interaction, including of quality practice toward service organization this study is examining these eight main factors.

The preparation and development of the questionnaires design, wording, quality-related activities scaleitem and statistical sampling plan were prepared in accordance to suggestions by Mizuno(1988), Goldratt,(1997), Dettmer(1995), Zikmund(2003), Warsworth et.al(2001), Hair et al (2000) Gryna et al (2003) to ensure the reliability and validity of the questionnaires. Scales used in the questionnaires is the six point Likert(1961) scale to measure the dependent variable- The numbers 1 through 6 represented a response to each statement of the independent variable in an item :1) Strongly Disagree; 2) Disagree; 3) Moderately Disagree; 4) Moderately Agree; 5) Agree; and 6) Strongly Agree

So as noted the above was an unbalanced rating scale with non neutral point. The respondents should to read the questions well smart before answering them. There are only two choices of level given, e.g. three choices of level of disagreement on scales 1 to 3 and three choices of level agreement on the scales of 4 to 6 . There is indecisive response like in the ordinary scale where in the middle there used to be a "neutral" or "neither agree nor disagree" choices. The reason for using a six point interval scale is to avoid respondents from ticking the weight in the middle value as commonly found in most surveys (Sekaran, 2003). This measure has also accommodates the needs of researcher for tapping variable. Indeed that the itemized rating scale provide the flexibility and extensively in most research.

For questions in section I (service organization), the following scale was used:1) Most unlikely; 2) Unlikely; 3) Moderately unlikely; 4) Moderately likely; 5) Likely; and 6) Most like

For questions, the respondents are asked to use the following scale: 1) Least probable; 2) Improbable; 3 ) Moderately improbably; 4) Moderately probably; 5) Probably; and 6) Most probably

The scale was used after deeply observe through more sample study and discuss with experts. However, no sample will ever fully represent the population in all aspects. This is said to be due sampling errors, which is reflected in the influence of chance in drawing the sample members or respondents (Sekaran, 2003) for each purpose, Schiling (1982) recommends specific attributes or variables sampling plans. Selection of a plan depends on the purpose, the quality history and the extent of knowledge of the process. The steps involved in the selection and reduced inspection costs. The row data from a neutral scale response become diagnostically useless to both the researcher and business decision maker. But that the neutral attitude or feeling; these psychology almost always have some level of a positive or negative orientation attached to them. The plan should minimize the total costs of inspection of all products. This requires careful evaluation of the pros and cons of attributes and variable plans, as well as multiple sampling. It should also reflect product priorities, particularly from the fitness-for-use viewpoint. Indeed than the plan should also provide information useful in estimating individual lot quality and long-run quality. Be Note that the plan should simple to explain and administer (Schilling, 1982, p. 564).

\subsection{Pilot Study}

Before distributing the questionnaires to the targeted respondents, a pilot study was conducted with several industry experts and academic professionals. Based on their feedback, structure leverage and modifications were made to enhance the clarity of the items. After incorporating feedback from a pre-test, the revised questionnaires was further pilot tested on a strategy operation company and included both company employees and customers. Numbers sets of questionnaires were administered to several expected and actual questionnaires administered to employees of strategy operation companies and numbers of expected and actual questionnaires were administered to the business of a strategy operation company. The number of items was reduced so that the time taken to complete the questionnaires becomes shorter. Therefore the reliability was also improved after several items were dropped and several statements were improved.

Beside that, the objective of conducting a pilot study is to test the reliability and validity of the questionnaires or tools used. The test on reliability of measurement is very important as it determine the stability and consistency of the measurement in order to avoid bias (Sekaran, 2003; Gryna et al., 2007). A copy of questionnaires, a covering lettering explaining the purpose of the pilot study (enclosed in Appendix A), and a paid envelope were sent to the respondents. Within four weeks, all questionnaires (both expected and actual) from the customers of the operation strategy were returned. As there were no reports of mixed and confusion about the questionnaires from either the strategy operation company or its partners, the questionnaires were not modified. 


\section{Conclusion}

In this part, focus on discussion of research strategy adopted for currents study. It covers three main aspects: 1) research design, 2) instruments development, variables e.g. dependent, independent, and moderator; and scale of measurement; 3) analysis tools. Perhaps the contribution is offer a significant advance to current literate studies of QMP on relation management for service quality.

In ensured the research design, the following presentation of statistical hypotheses to examine based on the research questions. The following then explain the data analysis, which were public hyper/ market frontline employees as middle/ top manager respondents of the retails in the center region of peninsular Malaysia. The procedures development is applied to examine QMP, contractual and structural networks, and relationship between QMP providers and their networks.

QMP is a management process and a set of disciplines that are co-ordinated to ensure that the organization consistently meets and exceeds customer requirements. TQM engages all divisions, departments and levels of the organization. Senior management organizes all of its strategy and operations around customer needs and develops a culture with high employee participation. Thus as aforementioned discussion, organization as the units of analysis for this purpose, data will have to be collected from each group of seven identical QMP and internal staff as respondents. These provide empirical evidence on the testable scales that is both valid and reliable in new theoretical with firm's performance. Importantly these management applicable to develop relevant and effective QMP strategies and tactics to improve on their relationships with customers constantly need to monitor their internal processes.

\section{References}

[1]. Anderson, J., Hakansson, H., and Johanson, J., (1994). Dyadic business relationships within a business network context, Journal of Marketing, 58, 1-15

[2]. Hofstede, G. (2001). Cultural consequences: Comparing values, behaviours, institutions, and organizations across nations. 2 ed. Thousand Oaks, CA: Sage

[3]. Cronin, J.J. Jr and Taylor, S.A. (1992), "Measuring service quality: a re-examination and extension”, Journal of Marketing, Vol. 56, pp. 55-68.

[4]. Brown, T. J., Churchill, G. A., Jr., \& Peter, J. P. (1992). Improving the measurement of service quality (Working Paper No. 92-4). Madison, WI: A.C. Nielsen Center for Marketing Research

[5]. Rust, R.T. and Zahorik, A.J. (1993), "Customer satisfaction, customer retention, and market share”, Journal of Retailing, Vol. 69 No. 2, Summer, pp. 193-216.

[6]. Greising, D.(1994), Quality: How to Make It Pay, Business Week August 8, pp. 54-59

[7]. Carman, J.M. (1990), "Consumer perceptions of service quality: an assessment of the SERVQUAL dimensions", Journal of Retailing, Vol. 66, Spring, pp. 33-55

[8]. Finn, D. W., Lamb, Jr., C. W.(1991), "An evaluation the SERVQUAL scales in a retail setting, in: Holman," R. H., Solomon. M. R. (Eds.), Advances in Consumer Research, Vol. 18, Association for Consumer Research, Provo, UT

[9]. Brown, T. 1.. Churchill. G. A. Jr., Peter, J. P.(1993), "Improving the measurement of service quality," Journal of Retailing, Vol. 69, No.1, pp. 127- 139.

[10]. 1 Maria Holmlund, (2007). Suggesting and Comparing Different Scopes on Quality Management: Production, Service, Relationship, and Network. Hanken Swedish School of Economics and Business Administration, Helsinki, Finland.

[11]. Frank M. Gryna, Richard C. H. Chua, Joseph A. Deofeo (2007). Juran's Quality Planning and Analysis for Enterprise quality $5^{\text {th }}$. ed.

[12]. Ulaga, W. (2001) Customer value in business markets: an agenda for inquiry, Industrial Marketing Management 30 (4), pp. 315319.

[13]. Cavinato, J. L. (2004) Supply chain logistics risks. From the back room to the board room, International Journal of Physical Distribution \& Logistics Management, 34(5), pp. 383-387.

[14]. Norrman, A. \& Jansson, U. (2004) Ericsson's proactive supply chain risk management approach after a serious sub-supplier accident, International Journal of Physical Distribution \& Logistics Management, 34(5), pp. 434-456

[15]. C.C. Changa*, C.M. Chiub and C.A. Chena, (2010). The effect of TQM practices on employee satisfaction and loyalty in government. Total Quality Management Vol. 21, No. 12, December 2010, 1299-1314

[16]. Gronroos, (2006). "Marketing theory". Journal of service research. Retrieved from http://en. Wikipedia. Org/ wiki/ Servicedominant - logic-(Marketing)

[17]. Irene $\mathrm{Ng}$, (2007). "Marketing theory". Journal of service research. Retrieved from http://en. Wikipedia. Org/ wiki/ Servicedominant - logic-(Marketing)

[18]. Arumugam, V., Ooi, K.B., Fong, T.C. (2008); TQM practices and quality management performance: An investigation of their relationship using data from ISO 9001:2000 firms in Malaysia. The TQM Magazine, 20(6), 636-650

[19]. Samson, D. and Terziovski, M. (1999), "The relationship between total quality management practices and operational performance", Journal of Operations Management, Vol. 17 No. 4, pp. 393-409.

[20]. Masahiro Miyagawa and Kosaku Yoshida, (2005). An empirical study of TQM practices in Japanese-owned manufacturers in China

[21]. 1 Liyin Jin, (2005). The Effects of Service Quality Management Practice on Customer Satisfaction

[22]. Peter K.C. Lee, W.M. To and Billy T.W. Yu, (2009). The implementation and performance outcomes of ISO 9000 in service organizations. An empirical taxanomy

[23]. Woan-Yuh Jang, Ching-I Lin, (2008),"An integrated framework for ISO 9000 motivation, depth of ISO implementation and firm performance: The case of Taiwan", Journal of Manufacturing Technology Management, Vol. 19 Iss: 2 pp. $194-216$

[24]. YUEN Sheung Man, (2006). Performance Measurement and Management of Third Party Logistics: An Organizational Theory Approach

[25]. Krajewski, L. J., Ritzman, L. P.(2002), Operations Management, Prentice Hall.

[26]. Leonard A. Schlesinger, (2003). "Hardwiring” an organization's service performance. Managing Service Quality Vol.13.no.1-2003. pp. 6-9 
[27]. Muhammad Asif Khan, 2011. TOTAL QUALITY MANAGEMENT AND ORGANIZATIONAL PERFORMANCEMODERATING ROLE OF MANAGERIAL COMPETENCIES INTERNATIONAL JOURNAL Of ACADEMIC RESEARCH Vol. 3. No. 5. September, 2011, II Part

[28]. Gummesson, E. (1998) Productivity, quality and relationship marketing in service operations, International Journal of Contemporary Hospitality Management, 10(1), pp. 4-16.

[29]. Silvestro, R. (1998) The manufacturing TQM and service quality literatures: synergistic or conflicting paradigms?, International Journal of Quality \& Reliability Management, 15(3), pp. 303-328.

[30]. Parasuraman, A. (2002) Service quality and productivity: a synergistic perspective, Managing Service Quality, 12(1), pp. 6-9.

[31]. Landrum, H., Prybutok, V. R., Strutton, D., \& Zhang, X. (2009). Examining the merits of usefulness versus use in an information service quality and information system success web-based model. Information Resources Management Journal, 21(2), 1-17.

[32]. Eitan Naveh, Alfred A. Marcus, (2004). When Does the ISO 9000 Quality Assurance Standard Lead to Performance Improvement? Assimilation and Going Beyond. IEEE Transactions on Engineering Management. Vol 51/3 (2004)

[33]. S.Bruce Han, Shaw K.Chen, Maling Ebrahimpour (2007). The Impact of ISO 9000 on TQM and Business Performance. Journal of Business and Economic Studies

[34]. Mehra, S. and Rhee, M. (2009); On the application of quality management concepts in education: An example of a Korean classroom. International Journal of Quality \& Reliability Management, Vol. 26 No. 4, 2009, pp. 312-324, Emerald Group Publishing Limited.

[35]. Toremen, F., Karakus, M., Yasan, T., (2009); Total quality management practices in Turkish primary schools. Quality Assurance in Education, Vol. 17 No. 1, 2009, pp. 30-44, Emerald Group Publishing Limited.

[36]. Joiner, T. A. (2007); Total quality management and performance: The role of organization support and co-worker support. International Journal of Quality \& Reliability Management, Vol. 24 No. 6, pp. 617-627. Emerald Group Publishing Limited

[37]. Sakthivel, P. B. and Raju, R. (2006); An instrument for measuring engineering education quality from students' perspective. The Quality Management Journal, 13(3), 23-34

[38]. Brendan, J. Gray, Sneelagh Matear and Philip K. Matheson (2002). Improving service firm performance. Journal of services marketing, Vol. 16 No. 32002 , pp $186-200$

[39]. Kuei, C-H. et al. (2001) The relationship between supply chain quality management practices and organizational performance, International Journal of Quality \& Reliability Management, 18(8), pp. 864-872.

[40]. Khalid, K. et al. (2006) Managing subcontractor supply chain for quality in construction, Engineering, Construction and Architectural Management, 13(1), pp. 27-42.

[41]. Mei Feng, Mile Terziovski, Danny Samson (2008). Relationship of ISO 9001:2000 quality system certification with operational and business performance. A survey in Australia and New Zealand-based manufacturing and service companies. Journal of Manufacturing Technology Management

[42]. Judith w.kincaid, (2003), Customer relationship management; getting it right, Publisher, Hewlett-Packard books, Prentice-Hall, Inc.

[43]. Christos V. Fotopoulos and Evangelos L. Psomas (2010). The structural relationships between TQM factors and organizational performance. The TQM Journal Vol. 22 No. 5, 2010 pp. 539-552 (3)

[44]. Arumugam, V., Ooi, K.B., Fong, T.C. (2008); TQM practices and quality management performance: An investigation of their relationship using data from ISO 9001:2000 firms in Malaysia. The TQM Magazine, 20(6), 636-650.

[45]. Aliah Hanim Mohd Yusof, (1999). Measuring service quality for Malaysian financial service and suggestions for future research, proceeding of the 3th Asian Academy of management conference, 16-17 July, Kuala Terengganu, Malaysia, pp. 403-409.

[46]. Mei Feng, Mile Terziovski, Danny Samson (2008). Relationship of ISO 9001:2000 quality system certification with operational and business performance. A survey in Australia and New Zealand-based manufacturing and service companies. Journal of Manufacturing Technology Management

[47]. T. Ramayah, Nusrah Samat and May-Chiun Lo (2011). Market orientation, service quality and organizational performance in service organizations in Malaysia. Asia-Pacific Journal of Business Administration Vol. 3 No. 1, 2011 pp. 8-27

[48]. Sakaran (2000)

[1]. Asubonteng, P., McCleary, K.J. and Swan, J.E. (1996), "SERVQUAL revisited: a critical review of service quality", Journal of Services Marketing, Vol. 10 No. 6, pp. 62-81

[49]. Sabrina Deutsch Salamon and Sandra L. Robinson, (2008). Trust That Binds: The Impact of Collective Felt Trust on Organizational Performance Journal of Applied Psychology Copyright 2008 by the American Psychological Association 2008, Vol. 93, No. 3, 593601

[50]. Berry, L. L. (1995). Relationship marketing of services - Growing interest, emerging perspectives, Journal of the Academy of Marketing Science, 23(4), 236-245

[51]. Lambert, D. C., and Stock, J. R. (1993). Strategic Logistics Management ( $3^{\text {rd }}$ Ed.). Homewood, IL: Richard D. Irwin.

[52]. Ross, D F. (1998). Competing through Supply Chain Management. New York: Champan and Hall.

[53]. Neely, A., Gregory, M., and Platts, K. (1995). Performance measurement system design: A literature review and research agenda, International Journal of Operations and Production Management, 15(4), 80-116.

[54]. Neely, A., Mills, J., Platts, K., Gregory, M., and Richards, H. (1996). Performance measurement system design: Should process based approach be adopted? International Journal of Production Economics, 16(3), 423-431.

[55]. Charles H. Kimzey and Sam Kurokawa, (2002). Technology Outsourcing in the U.S. and Japan. Technology Management@ 2002 Industrial Research Institute, Inc.

[56]. Deb Chartterji and Thomas a Manual (2001). Benefiting from external sources of technology. Research Technology Management; Nov/Dec 1993; 36, 6; ABI/INFORM Global pg. 21

[57]. Patrik Gottfridsson (2011). Development of new service in smaller organization: They Do Just Happen. Australia Journal of business and management research Vol. 1 No (91-99) October- 2011

[58]. Cann, C. W. (1995). Postpurchase marketing and relationship management, Ebrahimpour, M., Northeast Decision Institute 1995 Proceedings, $338-340$

[59]. Alston, J. P. (1989). Wa, guanxi, and inwha: Managerial principles in Japan, China and Korea, Business Horizons, 32, March-April, 26-31.

[60]. Luo, Y. (1997). Guanxi and performance of foreign-invested enterprises in China:

[61]. An empirical inquiry, Management International Review, 37(1), 51-70.

[1]. Pearce, J. A., and Robinson, R. B. (2000). Cultivating guanxi as a foreign investor strategy, Business Horizons, 1/2, 31-38.

[62]. Conway, T., and Swift, J. S. (2000). International relationship marketing - The importance of psychic distance, European Journal of Marketing, 34(11), 1391-1414.

[63]. Dwyer, F. R, Schurr, P. H., and Oh, S., (1987). Developing buyer-seller relationships, Journal of Marketing, 51, 11-27. 
[64]. Morgan, R. M., and Hunt, S. D. (1994), The commitment-trust theory of relationship marketing, Journal of Marketing, 58, 20-38

[65]. Sako, M. (1992). Prices, Quality, and Trust: Inter-firm Relations in Britain and Japan. Cambridge: Cambridge University Press.

[66]. Guandlach, G. T., Achrol, R. S., and Mentzer, J. T. (1995). The structure of commitment in exchanges, Journal of Marketing, 59(1), 78-92.

[67]. Helper, S. (1987). Supplier Relations and Innovation: Theory and Application to the U.S. Auto Industry, Ph.D. thesis, Harvard: Harvard University.

[68]. Lai, K. H., Cheng, T. C. E., and Yeung, A. C. L. (2005). Relationship stability and supplier commitment to quality, International Journal of Production Economics, 96, 397-410.

[69]. Anderson, J., Hakansson, H., and Johanson, J., (1994). Dyadic business relationships within a business network context, Journal of Marketing, 58, 1-15.

[70]. Tarı', J.J. and Molina, J.F. (2002), “Quality management results in ISO 9000 certified Spanish firms”, The TQM Magazine, Vol. 14 No. 4, pp. 232-9.

[71]. Choi, T. and Eboch, K. (1998), "The TQM paradox: relations among TQM practices, plant performance, and customer satisfaction", Journal of Operations Management, Vol. 17 No. 1, pp. 59-75.

[72]. Hendricks, K.B. and Singhal, V.R. (1997), "Does implementing an effective TQM program actually improve operating performance? Empirical evidence from firms that have won quality awards", Management Science, Vol. 43 No. 9, pp. 1258-74

[73]. Yang, C.C. (2006), "The impact of human resource management practices on the implementation of total quality management: an empirical study on high-tech firms", The TQM Magazine, Vol. 18 No. 2, pp. 162-73.

[74]. Hoque, Z. and James, W. (2000), "Linking balanced scorecard measures to size and market factors: impact on organizational performance", Journal of Management Accounting Research, Vol. 12 No. 1, pp. 1-17.

[75]. Malina, M.A. and Selto, F.H. (2004), "Choice and change of measures in performance measurement models", Management Accounting Research 15 No. 4, pp. 441-69.

[76]. Chenhall, R.H. (2005), "Integrative strategic performance measurement systems, strategic alignment of manufacturing, learning and strategic outcomes: an exploratory study", Accounting, Organizations and Society, Vol. 30 No. 5, pp. 395-422

[77]. Henri, J. (2006a), "Organizational culture and performance measurement systems", Accounting, Organizations and Society, Vol. 31 No. 1, pp. 77-103.

[78]. Lauren Skinner Beitelspacher, Mert Tokman, Frank G. Adams,and R. Glenn Richey, Jr (2012). Retail service-based operant resources and market performance. The International Journal of Logistics Management Vol. 23 No. 3, 2012 pp. 408-434

[79]. Gi-Du Kang, (2006),"The hierarchical structure of service quality: integration of technical and functional quality", Managing Service Quality, Vol. 16 Iss: 1 pp. $37-50$

[80]. Gronroos, C. (1984), “A service quality model and its marketing implication”, European Journal of Marketing, Vol. 18 No. 4, pp. 36-44.

[81]. Parasuraman, A., Zeithaml, V.A. and Berry, L.L. (1990), An Empirical Examination of Relationships in an Extended Service Quality Model, Marketing Science Institute, Cambridge, MA

[82]. Boo, H.V. (2006), "Linking a service-driven market orientation to service quality", Managing Service Quality, Vol. 16 No. 6, pp. 595-619.

[83]. Gronroos, C. (1984), “A service quality model and its marketing implication”, European Journal of Marketing, Vol. 18 No. 4, pp. 36-44.

[84]. Parasuraman, A., Zeithaml, V.A. and Berry, L.L. (1985), “A conceptual model of service quality and its implications

[85]. for future research", Journal of Marketing, Vol. 49, pp. 41-50.

[1]. Chia, M.C., Chin, T.C. and Chin, H.H. (2002), "A review of service quality in corporate and recreational sport/fitness programs", The Sport Journal, Vol. 5 No. 3, pp. 1-9.

[86]. Millissa F.Y. Cheung, W.M. To, (2010),"Management commitment to service quality and organizational outcomes", Managing Service Quality, Vol. 20 Iss: 3 pp. $259-272$

[87]. Masahiro Miyagawa and Kosaku Yoshida, (2005). An empirical study of TQM practices in Japanese-owned manufacturers in China

[88]. YUEN Sheung Man, (2006). Performance Measurement and Management of Third Party Logistics: An Organizational Theory Approach

[89]. Sekaran, U. (2003). Research Methods for Business: a Skill Building Approach. New York: John Wiley

[90]. Zikmund, W.G. (2003a). Business research methods ( $7^{\text {th }}$ ed.): Thomson.

[91]. Zikmund, W.G. (2003b). Exploring marketing ( $8^{\text {th }}$ ed.) Sydney: Thomson 